\title{
Beer-The Importance of Colloidal Stability (Non-Biological Haze)
}

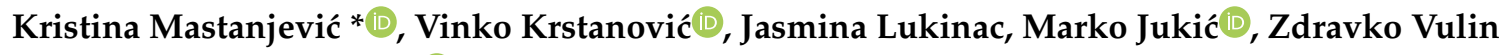 \\ and Krešimir Mastanjević $\mathbb{D}$
}

Faculty of Food Technology, University of Osijek, Osijek, F. Kuhača 20, 31000 Osijek, Croatia; vinko.krstanovic@ptfos.hr (V.K.); jasmina.lukinac@ptfos.hr (J.L.); marko.jukic@ptfos.hr (M.J.); zvulin@ptfos.hr (Z.V.); kmastanj@ptfos.hr (K.M.)

* Correspondence: khabschi@ptfos.hr; Tel.: +385-31-224-356

Received: 30 September 2018; Accepted: 24 October 2018; Published: 2 November 2018

check for updates

\begin{abstract}
Today's beer differs in many ways from the original hazy brew made from grains and water left in the sun to ferment. The development of brewing procedures introduced filtration and colloidal stabilization as key elements in beer preservation and stability. Colloidal stability of beer is the most important factor in beer quality. Colloidal particles significantly shorten beer's storage time, but most importantly, also influence its appearance. Colloidal stabilization involves one or more procedures that are applied at different stages during production and result in colloidal stability of the final product. Beer is considered to be colloidal stable if it can be stored for several months at $25^{\circ} \mathrm{C}$ without exhibiting any changes in composition or other properties; specifically, beer has to be able to remain clear without any signs of precipitation. Since colloidal stability is of primary importance for the consumer, retail requirements have resulted in many solutions for this issue. Stabilization agents have to be reliable during the filtration and stabilization processes. Additionally, renewable agents are highly desirable. The level of colloidal stability required depends on the desired storage time and temperature after the beer has been packed. Consumers have higher and higher expectations that the industry has to follow.
\end{abstract}

Keywords: beer; colloidal stability; quality

\section{Introduction}

Clarity is one of the most appealing characteristics of beer that drives consumption of products such as lagers and pilsners. Beer is considered clear and brilliant if no haze forms when chilled to four ${ }^{\circ} \mathrm{C}$ or below $[1,2]$. Consumers often perceive haziness as a defect and a potential health threat, and avoid hazy beers as a result. However, there are some exceptions to this rule. German and Belgium wheat (white) beers are designed to be hazy beers, and in their case, this is a highly desirable characteristic (Figure 1). The expansion of craft and organic beers is associated with a lack of filtration and chemical stabilization, which, in turn, results in hazy beers. Craft beer brewers often acknowledge the haziness of beer, and this can be a desirable characteristic for consumers of these types of beers.

Those familiar with lagers and pilsners expect these beers to exhibit a homogeneous, intense, and stable haze. However, in some cases it is difficult to fulfil these expectations and avoid haze formation [3]. Beer's clarity and other mentioned properties deteriorate with microbial (biological) and/or non-biological haze of a colloidal or physical-chemical nature that is generated during transport and storage.

Since colloidal haze is such an important quality indicator of beer, many studies have been carried out on filtrated pilsners and lagers [4-8]. According to these studies, the most frequent haze constituents are proteins and polyphenols. Polysaccharides, metal ions, hop resins, and melanoidins 
have also been reported as constituents of beer haze [9]. However, Siebert [10] referred to carbohydrates (starch, $\beta$-glucans and arabinoxylans) as being amongst the most important haze-forming compounds.

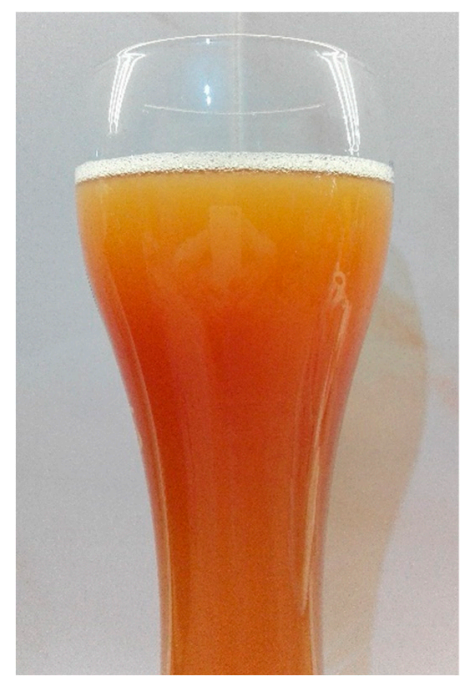

Figure 1. Haze in wheat beer.

\section{Types and Components of Beer Haze}

Generally, there are six types of beer stability, of which the first two are considered to be related to haze [11]:

1. Biological (microorganisms [12])-Fusarium spp. infections can also influence wort clarity. In research conducted on two wheat malt genotypes, Mastanjević et al. [13] reported that wort produced from samples infected with Fusarium culmorum showed a decrease in wort clarity.

2. Non-biological (physical [12])).

3. Foam (protein stability; Maillard reaction products; divalent metal ions such as zinc; foam stabilizers; foam inhibitors such as detergents and lipids) [14-17].

4. Flavor staling (oxygen, temperature [12]).

5. Light (sensitivity to visible and UV spectrum [18-20]).

6. Gushing (primary or secondary [21]).

In a review, Bamforth [12] divided physical (colloidal) instability of beer into several categories:

1. Precipitates.

2. Bits.

3. Haze.

4. Invisible haze.

There are several types of haze, and several classifications. Bamforth [22] generally divided haze into visible and invisible haze:

1. Visible haze (proteins and pentosanes): can shorten the shelf life of a product [23].

2. Invisible haze (pseudo-haze): caused by small particles $(<0.1 \mu \mathrm{m})[12,22]$.

Some sources, described in Bamforth [22] and Aron and Shellhammer [24], report visible haze as being a consequence of different factors:

1. Residual starch [25].

2. Pentosans (wheat adjuncts) [26]).

3. $\beta$-glucans [27]. 
4. Carbohydrates and proteins from yeast autolysis [28,29].

5. Lubricants [30],

6. Dead bacteria [31,32],

7. Metals (aluminum, barium, calcium, chromium, copper, iron, lead, magnesium, manganese, molybdenum, nickel, phosphorus, silicon, silver, strontium, tin, vanadium, and zinc) [33].

Glenister et al. [34], however, classifies haze particles in beer as:

1. Native particles, which originate from the beer by coagulation/precipitation,

2. Process particles, which originate from materials (e.g., filter aids) added during the process,

3. Foreign particles, which enter the beer as accidental contaminants.

In 2010 Steiner et al. [35] published an interesting paper on beer turbidity in which they observed several sources of haze:

1. Protein haze-beer contains approx. $500 \mathrm{mgL}^{-1}$ of different polypeptides. According to Kaersgaard and Hejgaard [36], only $2 \mathrm{mgL}^{-1}$ are sufficient to cause haze in beer.

2. $\alpha$-glucans

3. Calcium oxalate

4. Inorganic matter (filter aids, labels, glass particles, etc.)

Generally, there are three types of non-biological haze as reported by Leiper and Miedl [11]):

1. Chill haze (reversible) (Figure 2.); haze forms when beer is cooled to below $0{ }^{\circ} \mathrm{C}$, but disappears upon warming. It is a result of proteins that agglomerate together. While reversible, it must be attended to and treated because it can develop into permanent haze [22].

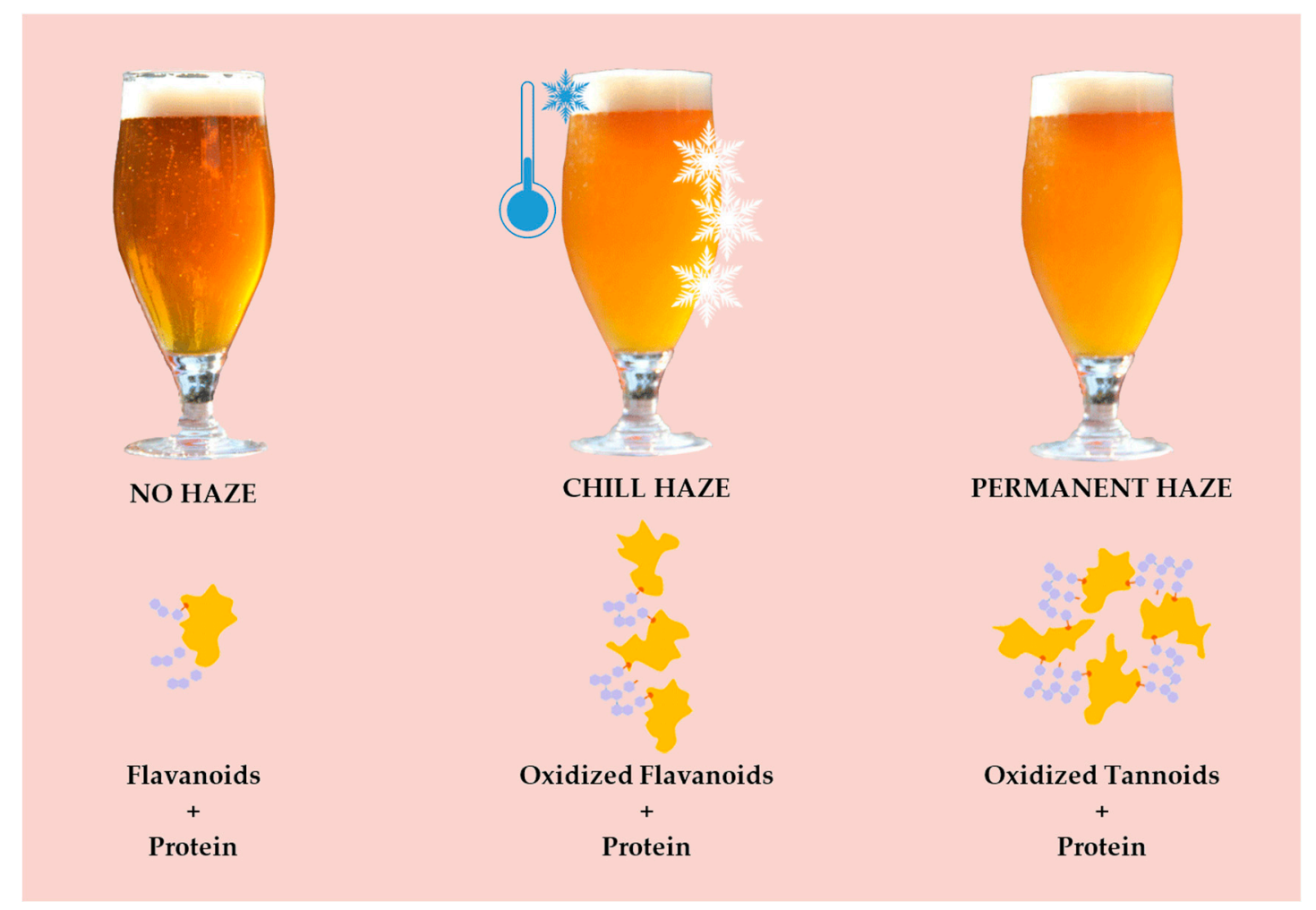

Figure 2. Chill and permanent haze development in beer. Adapted from [37].

2. Permanent (irreversible) (Figure 3)-protein + polyphenol; haze active (HA) proteins found in beer originate from barley's hordein protein fraction. HA-display a high affinity for polyphenols (PPs) and easily form haze [38]. Permanent haze can be caused by Reference [29]: 

a. oxidation
b. $\quad$ aging
c. shaking
d. metals
e. pasteurization

3. Haze caused by other substances (non-colloidal)

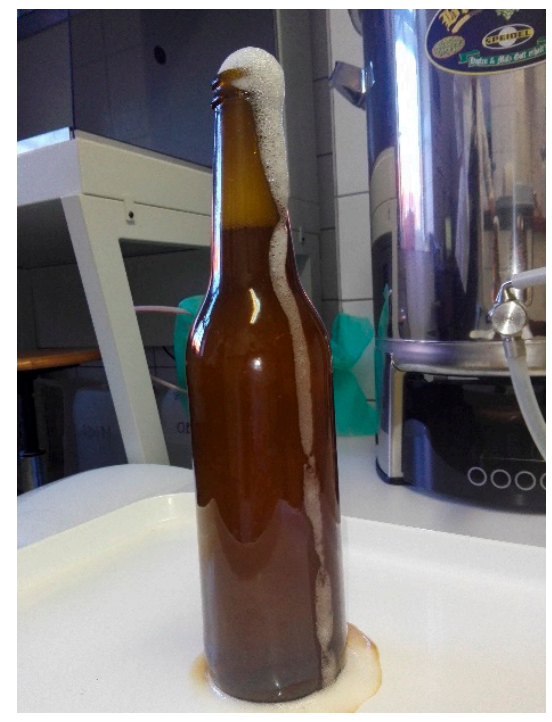

Figure 3. Permanent haze and gushing [21].

Chill and permanent haze are a result of reversible interactions between high molecular weight (HMW) polypeptides (hordein) and polyphenols (malt and hops). Covalent attachment (permanent haze) is preceded by ionic, hydrophobic, and hydrogen bonding causing chill haze. Polymerization of polyphenols may lead to covalent attachment with phenolic residues of amino acids in the polypeptide chain [38].

\section{How Beer Properties and Constituents Influence Haze Formation?}

1. $\mathrm{pH}-\mathrm{it}$ is well known that $\mathrm{pH}$ significantly influences proteins by determining their real charge. Changes in $\mathrm{pH}$ result in higher or lower molecular ionization, influence its solubility and space conformation. The optimal $\mathrm{pH}$ for haze formation is approx. 4.2-4.4. According to Siebert [10], lower $\mathrm{pH}$ significantly lessens haze formation.

2. Free amino acids do not influence beer haze because complexes between free amino acids and polyphenols are too small and much more soluble than protein-polyphenol complex [10].

3. Alcohol-haze reduction in solutions where alcohol is added can be explained by its polarity (lesser than water) and serves as a solvent in this case. Dioxan finds itself between water and alcohol according to polarity and his ability to reduce haze is greater than alcohol [39].

4. Carbohydrates- $\alpha$ - and $\beta$-glucans, pentosans/arabinoxylans, glucose, arabinose, polygalacturonic acid, and xylose contribute to haze formation in beer [29].

5. Metal ions-iron, copper, zinc, calcium and potassium ions have a tendency to accumulate haze particles. They catalyze oxidation of polyphenols and polymerization of polyphenols with proteins and help in turning reversible haze to permanent [40].

6. Oxygen-oxygen in beer encourages the formation of free radicals that deteriorate beer aroma and flavour compounds. This results in old and stale taste [29].

7. A simplified schemes of beer colloidal haze formation are shown in Figure 4. 


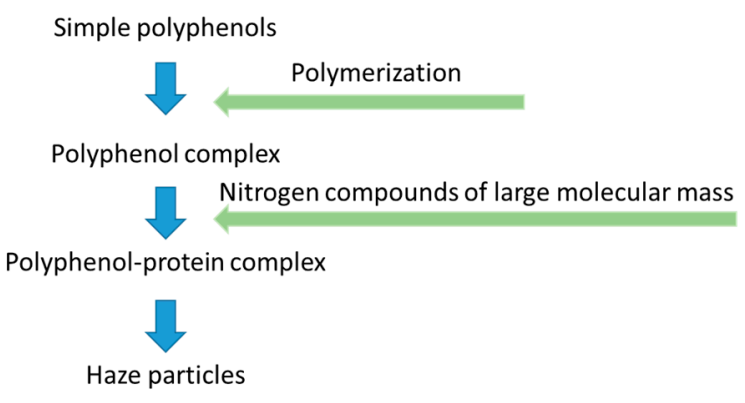

(a)

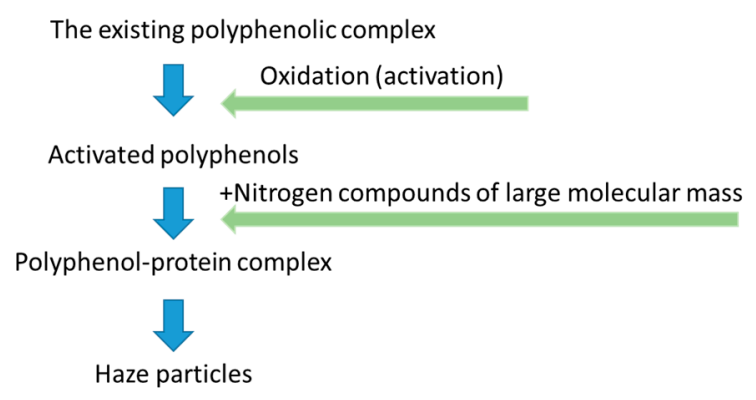

(b)

Figure 4. The two $(\mathbf{a}, \mathbf{b})$ hypothesis on beer colloidal haze formation.

\section{Physical-Chemical Properties of Beer}

Beer is a Newtonian type of solution whose colloidal stability is an important and extremely complicated-to-achieve quality indicator. All factors affecting colloidal stability are not yet determined [40,41]. Globalization of market prolonged the distribution time since routes have become longer, but the requirement for the beer to stay stable for a longer period of time stayed the same. In order to produce beer that will maintain clarity and brightness over a longer period of time, stabilization agents, and procedures became mandatory [42]. Even filtered beer can become hazy due to the colloidal haze formation during storage.

Polyphenols and proteins primarily form visible haze (turbidity), but interactions between polypeptides and polysaccharides, or polypeptides and minerals, can also contribute to the haziness of beer $[10,23,43,44]$. As beer is colloidal solution, it is consisted of different macromolecular organic particles that hold properties of reversible and irreversible coagulation and are usually of uneven structures. Beer colloids are lyophobic and lyophilic character. Particles forming haze are constructed from lyophilic colloids with electrical, osmotic, and optical properties. Electrical charge keeps the particles in colloidal condition since particles of the same charge repel and cannot form aggregates. Only when particles lose their charge they can form coagulates. Colloidal stability of beer mainly depends on particles that are not separated after stabilization/filtration processes and end up in final beer. These particles often hold specific aromas, taste, smell, colour, etc. [29]. Schur [45] ranges their size $0.5-3 \mu \mathrm{m}$ while Siebert et al. [46] divides these particles according to diameter to big $(1.0-2.9 \mu \mathrm{m})$ and small $(0.3-0.8 \mu \mathrm{m})$. The concentration of big particles is significantly correlating with nephelometric haze values, while the concentration of small particles does not correlate with it [46].

Detection of particles whose diameter is < one $\mu \mathrm{m}$ (mostly constructed of polyphenols and proteins) is of great importance for colloidal stability evaluation [39].

Haze particles size depend on concentration and type of turbidity precursors, the level of condensation and the speed of turbidity formation. Watched from the molecular-kinetical point of view, these particles can be annotated as aggregates, comprised from a number of molecules in constant irregular motion (Brownian motion). The random motion of particles suspended in a fluid (liquid or gas) results in their collision with the fast-moving molecules in the fluid, making bigger aggregates. Tyndall effect, the phenomenon where incident light is scattered by microscopic particles in suspension causes the visibility of haze in beer [3].

Siebert [10] described that hazy particles consist of mostly carbohydrates ( $>80 \%)$ coupled with proteins, while polyphenol share is pretty small, $1-2 \%$. According to a newer report by Steiner et al. [35], beer haze consists of several components: The most common compounds are proteins $(40-75 \%)$, polyphenols (in combination with proteins), and to a smaller proportion carbohydrates (2-15\%).

\section{Colloidal Stabilization Treatments}

Colloidal stabilization procedures have to be applied in accordance with economical, technological and ecological demands of the industry and legislation. Beers in need of longer storage time require 
application of additional stabilization procedures. There are different chemical and physical agents that help reduce proteins, polyphenols, polysaccharides, and metal ions. Predecessors of contemporary stabilization agents were wood chips, saw dust, aluminum dust, and glues [47].

The first step of ensuring colloidal stability is to exclude biological contaminants from the brewing process. Modern plants implement good hygiene practice and apply pasteurization and filtration processes [11] in order to minimize the possibility of microbiological contamination.

Natural process of precipitation of proteins occurs at lower temperatures and it ensures a clear and brilliant beer. Modern stabilization agents also work best at lower temperatures since the bonds between haze particles and treatment agent are prone to dissociate at higher temperatures [11].

The spectrum of colloidal stabilization agents has grown over the years and they give great results in prolonging the shelf life of a beer. They should be easy to remove from beer by precipitation or filtration. However, stabilization agents do tend to extract additional "beneficial" components, such as aroma and taste components, from beer during the segregation. For that reason, the treatment must be specific to selected substance that is being removed to avoid the wastage of other potentially favorable substances [44].

Most treatments and agents are oriented to remove proteins and/or polyphenols from beer. According to Leiper and Miedl [11], it is not necessary to remove all of the haze components, but just enough to ensure stability. In practice, stabilization agents can be introduced to lagering tank. However, it is better to add them when transferring beer from one thank to another because this ensures their better distribution in beer. Beer stabilization can be done point-blank before filtration or between first and second filtration. In any case, suitable gear and tanks for storage, preparation and dosage of stabilization agents must be ensured.

\section{Colloidal Stabilization Agents}

Some of the most used stabilization agents are grouped into several major chemicals $[11,29]$ and are shortly presented in Table 1:

1. Silica-commonly accepted stabilization agents

a. Silica gel-industrial preparation of sodium silicate; removes proteins responsible for causing haze. Silica has a highly porous structure to which proteins bind to.

b. Silica sol are used as aqueous solutions $(15-50 \% w / w)$ of silicic acid. In wort or beer, the sol cross-links to form a gel and traps haze-forming material. The gel is then removed during filtration. Sols are mostly used for wort clarification after boiling, but can be used to stabilize beer too [48].

2. Polyvinylpolypyrrolidine (PVPP)-PVPP is an adsorbent of great molecular weight, and unit molecular structure of PVPP closely resembles that of the amino acid proline [44]. It is not clear if the PVPP binds to the same part of the polyphenol molecule to which polypeptides bind, or another part, but binding to PVPP makes a strong relationship [49]. PVPP selectively binds to polyphenols responsible for chill and permanent haze. It is insoluble in water and organic solvents, strong acids, and alkali. Before use, it should be mixed with water and left for $15 \mathrm{~min}$ to bind water and allow swelling [50]. According to McMurrough [51], PVPP has no significant effect on haze-active polypeptide and Gopal and Rehmanji [50] report that it does not remove polyphenols that enable resistance to staling. PVPP can be used in two forms in brewing [11]:

a. In the form of a micronized powder, provided for single use. Particles are very small, but provide a large surface area. This can be added to the beer stream, with a necessary contact time of 5-10 min. This form can be dosed into the cold conditioning tank. Around $10-40 \mathrm{~g} / \mathrm{hl}$ should be used, and lower dosage are recommended if applied with silica gel. It is removed by filtration. 
b. Second form has larger particles, but provides smaller surface area and thus can adsorb less polyphenolic compounds. The upside is that this is recyclable and can be regenerated more times [50]. Regenerable PVPP can be added to the brewing process after primary filtration but has to be removed at a separate filter. Regeneration is done by washing with $\mathrm{NaOH}(1-2 \% w / v o l)$ at $60-80{ }^{\circ} \mathrm{C}$ for $15-30 \mathrm{~min}$, then with dilute acid to restore the $\mathrm{pH}$ to four. Regeneration losses are low as $0.5 \%$ have been claimed [50].

Single use PVPP can be combined with other agents, such as papain, tannic acid, silica gel, and kappa-carrageenan. However, because PVPP binds tannic acid, it has to be added after it and allow it to react first with the haze components.

In order to obtain the desired colloidal stability and increase the beer's shelf-life, it is necessary to reduce flavonoid polyphenols and their oxidized products to less than $5 \mathrm{mg} / \mathrm{L}$. The application of PVPP itself does not guarantee longer shelf-life [50], but the removal of oxidizable polyphenols can increase beer's shelf-life 20 times [52]. The downside of PVPP, as reported by Siebert and Lynn [44], is that it can reduce about $50 \%$ of haze-active polyphenols, but further reduction is practically impossible even if higher concentration of PVPP are added because of the fact that all binding sites are blocked with polyphenols. PVPP can significantly help remove other compounds: Prodelphinidin B3, procyanidin B3, catechin and epicatechin, gallocatechin, epigallocatechin, and proanthocyanidins [37,51]. Rehmanji et al. [50] gave better insight in the combined use of PVPP, silica xerogel and Polyclar Plus 730. As this mixture had particle of large size, it showed good filtration properties and a simultaneous removal of polypeptides, tannoids, and tannoid precursors.

1. Lucilite TR-Lucilite TR has been developed as an alternative to PVPP and even though it is derived from PVP-modified silica gel consisting of amorphous silica coated with, it does not require any time for swelling. For adsorption of polyphenols, it is most effective at lower dosages because at higher dosage, selectivity is poorer as non-haze-active polyphenols are also adsorbed [53].

2. Isinglass finings-made of natural piscine collagen (98\%) from tropical and subtropical fish swim bladders. It is rich in glycine, proline and hydroxyproline. In order to destroy the strong hydrogen bonds and produce soluble collagen, acid hydrolysis has to be applied. By increasing the size and weight of haze particles, finings cause haze particles to settle [11]. Isinglass can be found in four forms-liquid, milled, powdered or freeze dried, and paste. Isinglass molecule is amphoteric, meaning it is both negatively and positively charged. However, the total molecule charge can be described as positive with some negative areas and this is how isinglass can bind and negatively charged yeast cells and positively charged proteins. Ionic bonds are pointed to tannins, yeast cell walls and carrageenan, and hydrogen bonds to tannins, carrageenan and proteins. Since beer holds $\mathrm{pH}$ around 4.5 , and the optimal $\mathrm{pH}$ for isinglass is 4.4 , the removal of haze material works well. Isinglass is not allowed in finished beer as it is considered an allergen and some countries demanded it to be declared on food labels, since 2005. In 2015 an Annex II allergens was disclosed to Food allergen labelling and information requirements under the EU Food Information for Consumers Regulation No. 1169/2011: Technical Guidance [54] which included isinglass as an allergen. Walker et al. [55] published an article on the alternatives to isinglass for beer clarification, which included the application of yellow split peas and avian collagen.

3. Copper or kettle finings-these are actually carrageenan gels derived from the seaweed Euchema cottonii. Their main ingredients are linear sulphated polysaccharides containing galactose and anhydrogalactose. There are different types but so far $k$-type is the most effective in removing proteins, polypeptides, and polyphenols. They can be added $15 \mathrm{~min}$ before the end of the boil at $\mathrm{pH}>$ 5.2. As described in the chapter authored by Leiper and Miedl [11], copper finings give good wort clarity with a compact, stable, and easy-to-remove sediment. It is important to emphasize that they improve the clarity of cold wort by helping to precipitate trub, but are not so efficient when applied in hot wort. High gravity worts require more finings than normal gravity 
worts. The application of carrageenan or isinglass in filtered beers results in lower hazes than unfined beers.

4. Proteolytic preparations papain has a long history of usage in brewing industry. It was used to remove the albuminoids [56]. It is a mixture of proteinase enzymes obtained from the latex of the Carica papaya fruit. It hydrolyses beer proteins, but not only haze-causing proteins, and can act harmfully to the desirable foam active proteins. It can be applied after transfer to maturation tank or in maturation tank itself. Proteinase preparation-specific to haze-causing polypeptides. It is derived from the fungus Aspergillus niger, as reported by Lopez and Edens [57]. Beer treated with Clarex showed good haze stability following six months of storage at room temperature, with haze levels below $1.5^{\circ} \mathrm{EBC}$ and little effect on foam stability.

5. Tannic acid-has a structure formula resembling polyphenols; it can remove some metals ( $\mathrm{Fe}, \mathrm{Al}$, $\mathrm{Zn}$ and $\mathrm{Pb}$ ) and polyphenols if they are bound to proteins [58].

6. Gelatin is commonly used in the wine and juice industries to remove polyphenols. Gelatin removes haze proteins, but does not react with foam proteins [11].

7. Bentonite protein is an adsorbent consisting of alumino silicate with high swelling potential [29]. Damages foam stability [11].

8. Nylon perlon and polyamides are effective for the removal of polyphenols by adsorption, but affect bitterness, foam, and color [47].

9. Formaldehyde removal of polyphenols is forbidden in many countries for its cancerous properties [29].

10. Antioxidants-ascorbic acid and glucose oxidase are known reduce free radicals [47]. Ascorbic acid is considered to be a stand in for sulphur dioxide $\left(\mathrm{SO}_{2}\right)$. In presence of heavy metals it can have an adverse effect on beer quality. This is why it is usually added in synergy with some other reductor (K-metabisulphite) [29]. $\mathrm{SO}_{2}$ forms in beer naturally as a result of fermentation, but the original concentration is not sufficient to withhold a staling process. This is why $\mathrm{SO}_{2}$ is introduced to beer in the form of K-sulphite or sulphite acid [29]. Carbonyl-bisulphite adducts are complexes of sulphite. They act as antioxidants and help haze stability [59]. Other antioxidative compounds, hydrogen peroxide, or polyphenols, but are not accepted as EDTA, which is usually employed in heavy metal removal [47].

11. Combined treatments is a chamber filled with agarose adsorbent and when beer passes through the chamber haze-active proteins and polyphenols bind to the agarose that can be regenerated using salt and caustic, and is very economic since it can be used several hundreds of times without loss of performance [60]. 
Table 1. An overview of haze causes and means to reduce it.

\begin{tabular}{|c|c|c|c|c|c|}
\hline Instability Factor & Stabilization Agent & Technological Process of Application & Course of Action & Advantage & Shortcomings \\
\hline \multirow{5}{*}{$\begin{array}{l}\text { Polyphenolic } \\
\text { compounds }\end{array}$} & PVPP & Before or after filtration & adsorption & Lighter colour & \multirow{2}{*}{$\begin{array}{l}\text { Removal of low-molecular polyphenols } \\
\text { (decreased antioxidative potential) }\end{array}$} \\
\hline & Gelatin & & Precipitation & $\begin{array}{c}\text { Removes proteins } \\
\text { Leaves foam proteins intact }\end{array}$ & \\
\hline & Nylon & & adsorption & & damage bitterness, foam and colour \\
\hline & Formaldehyde & fermentation & $\begin{array}{l}\text { Polymerization and } \\
\text { precipitation }\end{array}$ & Lighter colour & Cancerous; forbidden for usage \\
\hline & Lucilite TR & & adsorption & & Effective with PVPP \\
\hline \multirow{5}{*}{ Proteins } & Bentonite & $\begin{array}{l}\text { Lagering tank, } 8 \text { days } \\
\text { before decantation }\end{array}$ & Non-selective adsorption & \multirow{4}{*}{$\begin{array}{l}\text { Increased filterability } \\
\text { Lighter colour }\end{array}$} & $\begin{array}{l}\text { Affects bitterness, colour, flavour and foam } \\
\text { Takes } 24 \mathrm{~h} \text { to react }\end{array}$ \\
\hline & Polyamide resin & Lagering tank, 1 day & adsorption & & Beer loss $1-3 \%$ \\
\hline & & before decantation & & & \multirow[b]{2}{*}{ Tend to dissolve in beer } \\
\hline & $\begin{array}{l}\text { Enzymes (papain, } \\
\text { proteinases) }\end{array}$ & Lagering tank or pressure tank & Hydrolysis & & \\
\hline & Silica gels and sols & $\begin{array}{l}\text { Gels are removed by filtration } \\
\text { Sols are used after boiling }\end{array}$ & & Commonly used & \\
\hline Carbohydrates & $\begin{array}{c}\text { Enzymes (amylase, } \\
\text { amyloglucosidase, glucanase) }\end{array}$ & Fermentation or lagering tank & & & $\begin{array}{l}\text { Foam instability } \\
\text { Tend to dissolve in beer }\end{array}$ \\
\hline \multirow{2}{*}{ Heavy metals } & EDTA & Fermentation & $\begin{array}{l}\text { Forming complexes } \\
\text { and precipitation }\end{array}$ & & Influences the potability \\
\hline & Tannic acid (Gallotannin) & $\begin{array}{l}\text { wort following boiling and } \\
\text { during maturation } \\
\text { filtration }\end{array}$ & & $\begin{array}{l}\text { effective against flavor staling and } \\
\text { light instability }\end{array}$ & It can damage foam proteins \\
\hline \multirow{5}{*}{ Oxygen } & Ascorbic acid & & \multirow{4}{*}{ reduction } & \multirow{2}{*}{ Lighter colour } & \multirow[b]{2}{*}{ Influences the potability } \\
\hline & $\begin{array}{l}\text { Enzymes (glucose-oxidase, } \\
\text { glucose-catalase) }\end{array}$ & Filtration & & & \\
\hline & $\begin{array}{c}\mathrm{SO}_{2} \mathrm{~K}-, \text { Na-sulphite } \\
\text { Carbonyl-bisulphite adducts }\end{array}$ & & & $\begin{array}{l}\text { Reduced oxidation and retards } \\
\text { staling Retards flavour deterioration }\end{array}$ & \\
\hline & Cystein, Lysin-HCl & & & & \multirow{2}{*}{ Influences the potability } \\
\hline & $\mathrm{CO}_{2}$ & & Physical removal & & \\
\hline \multirow{3}{*}{$\begin{array}{l}\text { Proteins and } \\
\text { polyphenols }\end{array}$} & agar & & adsorption & Does not influence foam stability & \\
\hline & Isinglass finings & & & & Declared as allergen \\
\hline & Copper finings & & & $\begin{array}{l}\text { give good wort clarity with a } \\
\text { compact, stable, } \\
\text { easy-to-remove sediment }\end{array}$ & \\
\hline
\end{tabular}




\section{Conclusions}

Beer haze is not a desirable characteristic, especially when it comes to lagers and pilsners. Wheat beers carry a different story and by tradition they are preferably hazy. Craft beers join in and bring to the market to an old school of beer enjoyment, where no filtration and clarification agents were available and beer was desirably blurry with different (mostly hoppy) taste. Today's industrial production ensures a clear and brilliant beer despite the globalization and huge distances that packed beer has to cross to get to the end user. The market for clearing agents and filtration techniques is growing and the targeted industry includes the brewing industry. With the introduction of new clearing agents or combining them, the brewing industry can be rest assured that beer will be satisfactory for the consumer. However, haze formation mechanisms and causes have to be better investigated and described and attention should be paid when combining clearing or other stabilizing agents in order to avoid unwanted precipitate and spoilage. Namely, temperatures during transport can rise and there have been cases where temperatures during transport arose to over $50{ }^{\circ} \mathrm{C}$ and gelatinous precipitate appeared as a result of the combining isinglass fining material and foam stabilizer propylene glycol alginate [22].

Author Contributions: Writing review \& Editing, K.M. (Kristina Mastanjević); Conceptualization, V.K.; Investigation, J.L.; Visualization, M.J.; Data Acquisition, Z.V.; Supervising, K.M. (Krešimir Mastanjević), all contributed equally.

Funding: This research received no external funding.

Conflicts of Interest: The authors declare no conflict of interest.

\section{References}

1. Briggs, D.E.; Boulton, C.A.; Brookes, P.A.; Stevens, R. Brewing: Science and Practice; Woodhead Publishing Limited: Cambridge, UK, 2004; p. 881.

2. Lewis, M.J.; Young, T.W. Brewing, 2nd ed.; Kluwer Academic and Plenum Publishers: New York, NY, USA, $2002 ;$ p. 398.

3. Delvaux, F.; Delvaux, F.R.; Delcour, J.A. Characterisation of the colloidal haze in commercial and pilot scale Belgian white beers. J. Inst. Brew. 2000, 106, 221-227. [CrossRef]

4. Anderegg, P. Inhibitors of filtration and filterability. Brauerei-Rundschau 1979, 10, 40-43.

5. Baetsle, G.O. Breweries set specific demands on use of wheat. Voedingsmiddelen-Techuologie 1996, 13, 43-45.

6. McMurrough, I.; Kelly, K.; Madigan, D. European Brewery Convention Congress. In Proceedings of the European Brewery Convention Congress, Oslo, Norway, 6-10 June 1993; Wijngaarden, M.V., Ed.; IRL Press: Oxford, UK, 1994.

7. Leipert, K.A.; Stewart, G.G.; McKeown, I.P. Beer polypeptides and silica gel Part, I. Polypeptides involved in haze formation. J. Inst. Brew. 2003, 109, 57-72. [CrossRef]

8. Leipert, K.A.; Stewart, G.G.; McKeown, I.P.; Nock, T.; Thompson, M.J. Optimising beer stabilisation by the selective removal of tannoids and sensitive proteins. J. Inst. Brew. 2005, 111, 118-127. [CrossRef]

9. Schur, F. Beer stabilization before filtration. Brauwelt 1980, 120, 1712-1716.

10. Siebert, K.J.; Carrasco, A.; Lynn, P.Y. Formation of protein polyphenol haze in beverages. J. Agric. Food Chem. 1996, 44, 1997-2005. [CrossRef]

11. Leiper, K.A.; Miedl, M. Colloidal stability of beer. In Handbook of Alcoholic Beverages Series, Beer: A Quality Perspective; Bamforth, C.W., Russell, I., Stewart, G., Eds.; Elsevier Ltd.: San Diego, CA, USA, 2009; Chapter 4.

12. Bamforth, C.W. 125th anniversary review: The non-biological instability of beer. J. Inst. Brew. 2011, 117, 488-497. [CrossRef]

13. Mastanjević, K.; Španić, V.; Horvat, D.; Mastanjević, K.; Šarkanj, B.; Krstanović, V.; Šantek, B. Establishing the impact of Fusarium culmorum infection and fungicide treatment on wheat malt quality. J. Food Process. Preserv. 2018, 17, e13714. [CrossRef]

14. Lusk, L.T.; Goldstein, H.; Ryder, D. Independent role of beer proteins, melanoidins and polysaccharides in foam formation. J. Am. Soc. Brew. Chem. 1995, 53, 93-103. [CrossRef] 
15. Roza, J.R.; Wallin, C.E.; Bamforth, C.W. A comparison between the instrumental measurement of head retention/lacing and perceived foam quality. Tech. Q. Master Brew. Assoc. Am. 2006, 43, 173-176.

16. Jackson, G.; Roberts, R.T.; Wainwright, T. Mechanism of beer foam stabilization by propylene glycol alginate. J. Inst. Brew. 1980, 86, 34-37. [CrossRef]

17. Bamforth, C.W. Bringing matters to a head: The status of research on beer foam. In Proceedings of the European Brewery Convention Congress Foam Symposium, Amsterdam, The Netherlands, 1998; Verlag Hans Carl, Getränke-Fachverlag: Nürnberg, Germany, 1999; pp. 10-23.

18. Goldstein, H.; Ting, P. Post kettle bittering compounds: Analysis, taste, foam and light stability. In Proceedings of the European Brewery Convention, Monograph XXII-Symposium on Hops, Zoeterwoude, The Netherlands, May/June 1994; Fachverlag Hans Carl: Nürnberg, Germany, 1994; pp. 154-162.

19. Lusk, L.T.; Murakami, A.; Nielsen, L.; Kay, S.; Ryder, D. Beer photooxidation creates two compounds with aromas indistinguishable from 3-methyl-2-butene-1-thiol. J. Am. Soc. Brew. Chem. 2009, 67, 189-192. [CrossRef]

20. Templar, J.; Arrigan, K.; Simpson, W.J. Formation, measurement and significance of lightstruck flavour in beer: A review. Brew. Dig. 1995, 70, 18-25.

21. Kristina, M.; Vinko, K.; Krešimir, M.; Bojan, Š. Malting and Brewing Industries Encounter Fusarium spp. Related Problems. Fermentation. 2018, 4, 3.

22. Bamforth, C.W. Beer haze. J. Am. Soc. Brew. Chem. 1999, 57, 81-90. [CrossRef]

23. Siebert, K.J.; Troukhanova, N.V.; Lynn, P.Y. Nature of polyphenol protein interactions. J. Agric. Food Chem. 1996, 44, 80-85. [CrossRef]

24. Aron, P.M.; Shellhammer, T.H. A discussion of polyphenols in beer physical and flavour stability. J. Inst. Brew. 2010, 116, 369-380. [CrossRef]

25. Letters, R. Origin of carbohydrates in beer sediments. J. Inst. Brew. 1969, 75, 54-80. [CrossRef]

26. Coote, N.; Kirsop, B.H. A haze consisting largely of pentosan. J. Inst. Brew. 1976, 82, 34. [CrossRef]

27. Gjertsen, P. Beta-glucans in malting and brewing. I Influence of beta-glucans on the filtration of strong beers. Proc. Am. Soc. Brew. Chem. 1966, 24, 113-120. [CrossRef]

28. Lewis, M.J.; Poerwantaro, W.M. Release of haze material from the cell walls of agitated yeast. J. Am. Soc. Brew. Chem. 1991, 49, 43-46. [CrossRef]

29. Krstanović, V. The Influence of Partial Substitution of Malt with Maize Grits and Wheat on Quality Parameters and Colloidal Stability of Beer. Master's Thesis, University of Zagreb, Zagreb, Croatia, July 2000.

30. Sharpe, F.R.; Channon, P.J. Beer haze caused by can lid lubricant. In Proceedings of the 21th Congress of European Brewery Convention, Madrid, Spain, 10-14 May 1987; pp. 599-606.

31. Bamforth, C.W. Processing and packaging and their effects on beer stability. Ferment 1988, 1, 49-53.

32. Walker, M.D.; Boume, D.T.; Wenn, R.V. The influence of malt-derived bacteria on the haze and filterability of wort and beer. In Proceedings of the 26th Congress of the European Brewery Convention, Maastricht, The Netherlands, 1997; pp. 191-198.

33. Bengough, W.I.; Harris, G. General composition of nonbiological hazes of beer and some factors in their formation. Part, I. J. Inst. Brew. 1955, 61, 134-135. [CrossRef]

34. Glenister, P.R. Beer Deposits: A Laboratory Guide and Pictorial Atlas for the Study of the Various Particles Found in the Deposits of Beer and Ale; Miles Laboratories: Chicago, IL, USA, 1975.

35. Steiner, E.; Becker, T.; Gastl, M. Turbidity and haze formation in beer-Insights and overview. J. Inst. Brew. 2010, 116, 360-368. [CrossRef]

36. Kaersgaard, P.; Hejgaard, J. Antigenic beer macromolecules: An experimental survey of purification methods. J. Inst. Brew. 1979, 85, 103-111. [CrossRef]

37. Rehmanji, M.; Mola, A.; Narayanan, K.; Gopal, C. Superior colloidal stabilization of beer by combined treatment with silica (Xerogel) and PVPP, polyclar plus 730. In Proceedings of the MBAA 112th Anniversary Conwention, Keystone, Colorado 1999 International Specialty Products, Wayne, NJ, USA, 2000; pp. 113-118.

38. Gorinstein, S.; Moshe, R.; Wolfe, F.H.; Berliner, M.; Rotenstreich, A.; Tilis, K. Characterization of stabilized and unstabilized beers. J. Food Biochem. 1990, 14, 161-172. [CrossRef]

39. Asano, K.; Shinagawa, K.; Hashimoto, N. Characterization of haze-forming proteins of beer and their roles in chill haze formation. J. Am. Soc. Brew. Chem. 1982, 40, 147-154. [CrossRef]

40. Anger, H.M. Assuring nonbiological stability of beer as an important factor for guaranteeing minimum self-life. Brauwelt Int. 1996, 2, 142-150. 
41. Leonel, M.; Moll, M.; Dodds, J.A.; Leitzelement, M. Beer colloidal haze and the filtration process. MBAA Tech. Q. 1986, 23, 44-48.

42. Titze, J.; Christian, M.; Jacob, F.; Parlar, H.; Ilberg, V. The possibilities of particle analysis demonstrated by the measurement of the colloidal stability of filtered beer. J. Inst. Brew. 2010, 116, 405-412. [CrossRef]

43. Siebert, K.J. Effects of protein polyphenol interactions on beverage haze, stabilization, and analysis. J. Agric. Food Chem. 1999, 47, 353-362. [CrossRef] [PubMed]

44. Siebert, K.J.; Lynn, P.Y. Mechanism of beer colloidal stabilization. J. Am. Soc. Brew. Chem. 1997, 55, 73-78. [CrossRef]

45. Schur, F. Beer stabilization. Schweiz. Brau. Rundsch. 1979, 90, 4-12.

46. Siebert, K.J.; Stenroos, L.E.; Reid, D.S. Characterization of amorphous-particle haze. J. Am. Soc. Brew. Chem. 1981, 39, 1-11. [CrossRef]

47. Basarova, G. The structure-function relationship of polymeric sorbents for colloidal stabilization of beer. Food Struct. 1990, 9, 175-194.

48. Niemsche, K.; Oppermann, A. Clarification of wort and beer with silica sol. Brew. Int. 2004, 4, 30-32.

49. McMurrough, I.; O'Rourke, T. New insight into the mechanism of achieving colloidal stability. MBAA Tech. Q. 1997, 34, 271-277.

50. Gopal, C.; Rehmanji, M. PVPP—The route to effective beer stabilisation. Brew Guard 2000, 129, 1-4.

51. McMurrough, I. Colloidal stabilization of beer. Ferment 1995, 8, 39-45.

52. McMurrough, I.; Madigan, D.; Kelly, R.J.; Smyth, M.R. The role of flavanoid polyphenols in beer stability. J. Am. Soc. Brew. Chem. 1996, 54, 141-148. [CrossRef]

53. Rehmanji, M.; Mola, A.; Narayanan, K.; Gopal, C. Superior colloidal stabilization of beer by combined treatment with silica (xerogel) and PVPP, polyclar plus 730. MBAA Tech. Q 2000, 37, 113-118.

54. Food Allergen Labelling and Information Requirements under the EU Food Information for Consumers Regulation No. 1169/2011: Technical Guidance. Available online: https:/ /www.food.gov.uk/sites/default/ files/media / document/food-allergen-labelling-technical-guidance.pdf (accessed on 12 October 2018).

55. Walker, S.L.; Donet Camarena, M.C.; Freeman, G. Alternatives to isinglass for beer clarification. J. Inst. Brew. 2007, 113, 347-354. [CrossRef]

56. Esnault, E. Beer stabilization with papain. Brew Guard 1995, 124, 47-49.

57. Lopez, M.; Edens, L. Effective prevention of chill-haze in beer using an acid proline-specifi c endoprotease from Aspergillus niger. J. Agric. Food Chem. 2005, 53, 7944-7949. [CrossRef] [PubMed]

58. Mussche, R.A. Beer stabilization with gallotannin. Brew Guard 1994, 123, 44-49.

59. Kaneda, H.; Osawa, T.; Kawakishi, S.; Munekata, M.; Koshino, S. Contribution of carbonyl-bisulfi te adducts to beer stability. J. Agric. Food Chem. 1994, 42, 2428-2432. [CrossRef]

60. Jany, A.; Katzke, M. CSS-A new beer stabilization process. MBAA Tech. Q. 2002, 39, 96-98. 